\title{
Estimation of Genetic Parameters in Groundnut (Arachis hypogaea L.) for Yield and It's Contributing Characters under Inorganic Fertilizer Managements
}

\author{
P. Aparna*, M. Shanthi Priya, D. Mohan Reddy and P. Latha
}

Department of Genetics and Plant Breeding, S.V. Agricultural College, Tirupati 517502, Chittoor district, Andhra Pradesh, India

*Corresponding author

\begin{tabular}{|c|c|}
\hline & B S \\
\hline & \multirow{5}{*}{$\begin{array}{l}\text { In the present investigation } 168 \text { germplasm lines and five checks of groundnut were } \\
\text { evaluated during Kharif } 2016 \text { to study genetic parameter viz., variability, heritability and } \\
\text { genetic advance for fourteen characters. The analysis of variance for all quantitative } \\
\text { characters revealed that the presence of ample amount of genetic variation for all the } \\
\text { characters among the entries. The traits; number of immature pods per plant, kernel yield } \\
\text { per plant, number of primary branches per plant, number of mature pods per plant, pod } \\
\text { yield per plant, number of pegs per plant and number of pods per plant were recorded } \\
\text { higher estimates of GCV and PCV. High heritability coupled with high genetic advance as } \\
\text { per cent of mean were registered by number of immature pods per plant followed by days } \\
\text { to } 50 \% \text { flowering, number of primary branches per plant, shelling percentage, number of } \\
\text { pods per plant, number of mature pods per plant, plant height and } 100 \text { kernel weight. The } \\
\text { above results indicating that these traits were mainly governed by additive gene action and } \\
\text { scope for the improvement of these traits through selection. }\end{array}$} \\
\hline & \\
\hline $\begin{array}{l}\text { Groundnut, Genetic } \\
\text { parameters, } \\
\text { Inorganic fertilizer } \\
\text { managements }\end{array}$ & \\
\hline Article Info & \\
\hline $\begin{array}{l}A c \\
12 \\
A v \\
10\end{array}$ & \\
\hline
\end{tabular}

\section{Introduction}

Groundnut is the major oilseed crop of India. The groundnut kernel has dual advantage of being important as a source of edible oil as well as protein. It is native of Brazil. Groundnut (Arachis hypogaea L.) is annual legume allotetraploid species with $2 \mathrm{n}=40$ widely cultivated under rain-fed conditions in arid and semi-arid regions of the world. The success of any breeding programme depends on the amount of variability present for different characters in a population. A plant population with higher genetic variability provides greater opportunity for improvement. The genetic coefficient of variability gives an useful measure of the magnitude of genetic variance present in the population. The amount of genetic variation considered alone will not be of much use to the breeder unless supplemented with the information on heritability estimate, which gives a measure of the heritable portion of the total variation. It has been suggested by Burton and Devane (1953) that GCV along with heritability estimate could provide a better picture of the amount of advance to be expected by phenotypic selection. Since genetic advance is 
dependent on phenotypic variability and heritability in addition to selection intensity, the heritability estimates in conjunction with genetic advance will be more effective and reliable in predicting the response to selection (Johnson et al., 1955a). We can also assess the nature of gene action by estimating genetic advance together with heritability. Therefore, in the present investigation an attempt was made to assess genetic variability, heritability and genetic advance among various traits in 168 germplasm lines and five checks of groundnut.

\section{Materials and Methods}

\section{Study site and experimental design}

Experimental material used for this study consisted of 168 germplasm lines and five checks of groundnut. These were planted in Augmented design II at dryland farm of S.V. Agricultural college, Tirupathi during kharif, 2016. Each entry was accommodated in a single row of $2 \mathrm{~m}$ length with a spacing of 30 $\mathrm{x} 10 \mathrm{~cm}$. Recommended dose of chemical fertilizers @ of $20 \mathrm{~kg} \mathrm{~N}, 40 \mathrm{~kg} \mathrm{P}_{2} \mathrm{O}_{5}$ and $40 \mathrm{~kg}$ $\mathrm{K}_{2} \mathrm{O}$ per hectare in the form of urea, single super phosphate and murate of potash were broadcasted before sowing. Seed treatment was done with bavistin @ of $3 \mathrm{~g} \mathrm{~kg}^{-1}$. For the control of insect pests chlorofenopyr@ $2 \mathrm{ml} \mathrm{l}^{-}$

1 was used. Gypsum @ 500 kg ha ${ }^{-1}$ was applied at pegging stage.

\section{Data collection}

In each germplasm line five competitive plants were selected at random to record observations for fourteen traits viz., days to 50 $\%$ flowering, days to maturity, plant height (cm), number of primary branches per plant, number of pegs per plant, number of mature pods per plant, number of immature pods per plant, total number of pods per plant, 100 seed weight $(\mathrm{g})$, shelling percentage $(\%)$, sound mature kernel percentage (\%), harvest index $(\%)$, kernel yield per plant (g) and pod yield per plant (g).

\section{Statistical analysis}

The analysis of variance was calculated by using Fisher and Yates (1967) method. The genotypic coefficient of variance (GCV) and phenotypic coefficient of variance (PCV) was estimated by the formulae given by Burton (1952)). Heritability in broad sense was computed by the formulae given by Lush (1940). From the heritability estimates, the genetic advance over mean was determined as per the procedure of Johnson et al., (1955a).

\section{Results and Discussion}

The analysis of variance for all studied characters is presented in Table 1, which showed that the mean sum of squares due to entries showed significant difference for all quantitative characters considered under study. This indicating that the significant difference for the characters among the entries was mainly due to the presence of considerable amount of genetic variation.

The traits such as number of pegs per plant, sound mature kernel percentage, harvest index, total number of pods pert plant and shelling percentage recorded highest range of variation, while least range of variation was observed for number of immature pods per plant, number of primary branches per plant and days to $50 \%$ flowering (Table 2). The highest magnitude of genotypic and phenotypic variance was observed for number of pegs per plant, whereas the least estimates of genotypic and phenotypic variance were recorded for number of immature pods per plant. The estimates of phenotypic coefficient of variation were higher than genotypic coefficient of variation for all the 14 characters indicating the influence of 
environment in the expression of these traits. Similar kind of observations were also reported by Zaman et al., (2011), Satish (2014), Vasanthi et al., (2015), Jibrin et al., (2016) and Kamde et al., (2017).

The highest estimates of GCV and PCV were registered for number of immature pods per plant, kernel yield per plant, number of primary branches per plant, number of mature pods per plant, pod yield per plant, number of pegs per plant and number of pods per plant indicating the presence of ample amount of variation among the genotypes for these traits. The estimates of high GCV and PCV for number immature pods per plant were in accordance with the reports of John et al., (2009). Results of high variability estimates for pod yield per plant and kernel yield per plant were similar to the reports of Parameswarappa et al., (2005), John et al., (2008), Meta and Monpara (2010), Jonah et al., (2012) and Patidar et al., (2014). The reports of John et al., (2008) and Gupta et al., (2015) were similar to the present report of high variability for number of mature pods per plant. The high variability estimates noticed for number of pegs per plant and number of primary branches per plant was in consonance with results of Korat et al., (2009) and Parameshwarappa et al., (2005) respectively. John et al., (2009) reported high variability estimates for number of pods per plant. The traits viz., sound mature kernel percentage, harvest index, plant height and 100 kernel weight recorded moderate estimates of GCV and high PCV values. The results of Vasanthi et al., (2015) and Bhargavi et al., (2016) were similar to the present report of moderate GCV and high PCV estimates for 100 kernel weight and harvest index, respectively. Moderate estimates of GCV and PCV were observed for days to $50 \%$ flowering and shelling percentage. Moderate estimates of GCV and PCV recorded for days to $50 \%$ flowering and shelling percentage were in accordance with the results of Patil et al., (2014) and Zaman et al., (2011) respectively. On contrary days to maturity showed lower estimates of coefficient of variation. The lower estimates of variability for days to maturity were in agreement with the reports of Patil et al., (2014) and Shukla and Rai (2014), thereby indicating narrow genetic variability for these characters in the material studied.

High heritability estimates were registered for number of immature pods per plant followed by days to $50 \%$ flowering, days to maturity, number of primary branches per plant, shelling percentage, number of pods per plant, number of mature pods per plant, plant height and 100 kernel weight which indicated that environment had least influence on the expression of these traits. All traits except days to maturity exhibited higher estimates of genetic advance as per cent of mean indicated that these traits were governed by additive genes and selection will be rewarding for improvement of such traits

High heritability coupled with high genetic advance as per cent of mean were recorded for number of immature pods per plant followed by days to $50 \%$ flowering, number of primary branches per plant, shelling percentage, number of pods per plant, number of mature pods per plant, plant height and 100 kernel weight. Similar results were reported for number of immature pods per plant, plant height, days to $50 \%$ flowering and 100 seed weight by Zaman et al., (2011), John et al., (2013), Sudhir et al., (2008) and Bhargavi et al., (2016) respectively. High heritability coupled with high genetic advance as per cent of mean for number of primary branches per plant and shelling percentage was in accordance with the results of Satish (2014) and Narasimhulu et al., (2012), respectively, suggesting that additive gene action in expression of these traits and selection would be effective for improvement of these traits. 
Table.2 Estimates of variability and genetic parameters for 14 characters in 168 germplasm lines and five checks under inorganic fertilizer management

\begin{tabular}{|c|c|c|c|c|c|c|c|c|c|c|c|}
\hline \multirow[t]{2}{*}{$\begin{array}{l}\text { S. } \\
\text { No. }\end{array}$} & \multirow[t]{2}{*}{ Character } & \multirow[t]{2}{*}{ Mean } & \multicolumn{2}{|c|}{ Range } & \multicolumn{2}{|c|}{ Variance } & \multicolumn{2}{|c|}{$\begin{array}{l}\text { Coefficient of } \\
\text { Variation (\%) }\end{array}$} & \multirow{2}{*}{$\begin{array}{c}\text { Heritabili } \\
\text { ty (Broad } \\
\text { sense) } \\
(\%)\end{array}$} & \multirow{2}{*}{$\begin{array}{c}\text { Genetic } \\
\text { Advance } \\
\text { (GA) }\end{array}$} & \multirow{2}{*}{$\begin{array}{c}\text { Genetic } \\
\text { advance as } \\
\text { percent of } \\
\text { mean }(\%)\end{array}$} \\
\hline & & & Min & $\operatorname{Max}$ & Genotypic & $\begin{array}{l}\text { Phenotypi } \\
\text { c }\end{array}$ & Genotypic & $\begin{array}{l}\text { Phenotypi } \\
\text { c }\end{array}$ & & & \\
\hline 1. & Days to $50 \%$ flowering & 30.73 & 24.00 & 37.00 & 14.78 & 16.41 & 12.51 & 13.18 & 90.05 & 7.51 & 24.45 \\
\hline 2. & Days to maturity & $\begin{array}{l}117.7 \\
6\end{array}$ & 102.00 & 127.00 & 49.83 & 57.63 & 5.99 & 6.45 & 86.47 & 13.52 & 11.48 \\
\hline 3. & Plant height $(\mathrm{cm})$ & 28.42 & 7.80 & 43.40 & 25.44 & 35.87 & 17.74 & 21.07 & 70.91 & 8.75 & 30.78 \\
\hline 4. & $\begin{array}{l}\text { Number of primary } \\
\text { branches per plant }\end{array}$ & 5.72 & 3.40 & 15.00 & 3.90 & 4.67 & 34.53 & 37.79 & 83.49 & 3.71 & 65.00 \\
\hline 5. & Number of pegs per plant & 44.97 & 16.20 & 112.00 & 124.66 & 228.21 & 24.83 & 33.59 & 54.62 & 17.00 & 37.80 \\
\hline 6. & $\begin{array}{l}\text { Number of mature pods per } \\
\text { plant }\end{array}$ & 17.78 & 3.80 & 35.40 & 31.48 & 43.53 & 31.56 & 37.11 & 72.32 & 9.83 & 55.29 \\
\hline 8. & Number of pods per plant & 21.68 & 5.26 & 40.40 & 38.12 & 52.43 & 28.48 & 33.40 & 72.71 & 10.85 & 50.03 \\
\hline 9. & 100 kernel weight (g) & 23.76 & 13.45 & 38.06 & 15.91 & 24.61 & 16.79 & 20.88 & 64.65 & 6.61 & 27.81 \\
\hline 10. & Shelling percentage & 55.92 & 26.09 & 73.20 & 45.14 & 59.09 & 12.01 & 13.75 & 76.39 & 12.10 & 21.63 \\
\hline 11. & $\begin{array}{l}\text { Sound mature kernel } \\
\text { percentage }\end{array}$ & 49.64 & 11.06 & 78.70 & 91.62 & 173.31 & 19.28 & 26.52 & 52.87 & 14.34 & 28.88 \\
\hline 12. & Harvest index (\%) & 33.38 & 6.99 & 56.92 & 41.01 & 69.31 & 19.18 & 24.94 & 59.18 & 10.15 & 30.40 \\
\hline 13 & Kernel yield per plant (g) & 7.12 & 1.04 & 14.95 & 4.48 & 8.95 & 29.73 & 42.02 & 50.06 & 3.08 & 43.32 \\
\hline 14 & Pod yield per plant (g) & 12.56 & 2.14 & 24.25 & 11.37 & 21.55 & 26.84 & 36.95 & 52.76 & 5.05 & 40.16 \\
\hline
\end{tabular}


Table.1 Analysis of variance for 14 characters in 168 germplasm lines and five checks of groundnut under inorganic fertilizer management

\begin{tabular}{|c|l|c|c|c|c|}
\hline $\begin{array}{c}\text { S. } \\
\text { No }\end{array}$ & \multicolumn{1}{|c|}{ Character } & $\begin{array}{c}\text { Block } \\
(\mathbf{d f = 5})\end{array}$ & $\begin{array}{c}\text { Entries } \\
(\mathbf{d f = 1 7 2})\end{array}$ & $\begin{array}{c}\text { Checks } \\
(\mathbf{d f = 4})\end{array}$ & $\begin{array}{c}\text { Error } \\
(\mathbf{d f}=\mathbf{2 0})\end{array}$ \\
\hline $\mathbf{1}$ & Days to 50\% flowering & $5.20^{*}$ & $16.41^{* *}$ & $33.13^{* *}$ & 1.63 \\
\hline $\mathbf{2}$ & Days to maturity & $27.10^{*}$ & $57.63^{* *}$ & $104.00^{* *}$ & 7.80 \\
\hline $\mathbf{3}$ & Plant height (cm) & 21.10 & $35.87^{* *}$ & $183.57^{* *}$ & 10.44 \\
\hline $\mathbf{4}$ & $\begin{array}{l}\text { Number of primary branches per } \\
\text { plant }\end{array}$ & 1.44 & $4.67^{* *}$ & $7.20^{* *}$ & 0.77 \\
\hline $\mathbf{5}$ & Number of pegs per plant & $387.03^{*}$ & $228.21^{*}$ & 155.58 & 103.56 \\
\hline $\mathbf{6}$ & Number of mature pods per plant & $38.58^{*}$ & $43.53^{* *}$ & $59.36^{* *}$ & 12.05 \\
\hline $\mathbf{7}$ & Number of immature pods per plant & $0.96^{*}$ & $4.22^{* *}$ & $2.78^{* *}$ & 0.35 \\
\hline $\mathbf{8}$ & Number of pods per plant & $41.26^{*}$ & $52.43^{* *}$ & $71.59^{* *}$ & 14.31 \\
\hline $\mathbf{9}$ & 100 kernel weight (g) & 18.25 & $24.61^{* *}$ & $72.06^{* *}$ & 8.70 \\
\hline $\mathbf{1 0}$ & Shelling percentage & 18.53 & $59.09^{* *}$ & $154.232^{* *}$ & 13.95 \\
\hline $\mathbf{1 1}$ & Sound mature kernel percentage & 15.30 & $173.31^{*}$ & $397.83^{* *}$ & 81.68 \\
\hline $\mathbf{1 2}$ & Harvest index (\%) & 53.99 & $69.31^{*}$ & 43.38 & 28.29 \\
\hline $\mathbf{1 3}$ & Kernel yield per plant (g) & $14.33^{*}$ & $8.95^{*}$ & $13.62^{*}$ & 4.47 \\
\hline $\mathbf{1 4}$ & Pod yield per plant (g) & $34.23^{*}$ & $21.55^{*}$ & $41.19^{*}$ & 10.18 \\
\hline ** indicate significant at 5\% and 1\% level of probability & & & & \\
\hline
\end{tabular}

The characters, harvest index, number of pegs per plant, sound mature kernel percentage, pod yield per plant and kernel yield per plant exhibited moderate heritability coupled with high genetic advance as per cent of mean. Moderate heritability coupled with high genetic advance as per cent of mean recorded for harvest index by Gupta et al., (2015) indicated that improvement of these traits possible by simple pedigree method of breeding and phenotypic selection. High heritability coupled with moderate genetic advance as per cent of mean was registered for days to maturity. These results were in conformity with Kadam et al., (2007) and Bhargavi et al., (2016).

The high genetic variability in the form of phenotypic coefficient of variation (PCV) and genotypic coefficient of variation (GCV) was observed for number of immature pods per plant, kernel yield per plant, number of primary branches per plant, number of mature pods per plant, pod yield per plant, number of pegs per plant and number of pods per plants. High to moderate heritability of these traits indicates that whatever variation occurred is mainly due to genetic causes and less influenced by the environment. As these characters were exhibited high GCV and high heritability coupled with high genetic advance priority should be given for these traits during selection process.

\section{References}

Bhargavi, G., Rao, V.S and Rao, K.L.N. 2016. Genetic variability, heritability and genetic advance of yield and related traits of Spanish bunch groundnut (Arachis hypogaea L.). Agricultural Science Digest. 36 (1): 60-62.

Burton, G.W and Devane. 1953. Estimating heritability in tall fescue (Festula arundnacea L.) from replicated clonal 
material. Agronomy Journal. 45: 478481.

Burton, G.W. 1952. Quantitative inheritance in grasses. Proceedings of Sixth International Grassland Congress. 1: 277-283.

Fisher, R.A and Yates, F. 1967. Statistical tables for biological, agricultural and medical research. Oliver and Boyd, London, pp. 44-63.

Gupta, R. P., Vachhani, J. H., Kachhadia, V. H., Vaddoria, M. A. and Reddy, P. 2015. Genetic variability and heritability studies in Virginia groundnut (Arachis hypogaea L.). Electronic Journal of Plant Breeding. 6 (1): 253-256.

Jibrin, M.S., Habu, S.H., Echekwu, C.A., Abdullahi, U.S and Usman, I.S. 2016. Phenotypic and genotypic variance and heritability estimates for oil content and other agronomic traits in groundnut (Arachis hypogaea L.). International Journal of Scientific Research and Engineering Studies. 3 (3): 29-32.

John, K., Vasanthi, R.P and Venkateswarlu, O. 2009. Studies on variability and character association in Spanish bunch groundnut (Arachis hypogaea L.). Legume Research. 32 (1): 65-69.

John, K., Vasanthi, R.P and Venkateswarlu, O. 2008. Variability and correlation studies for pod yield and its attributes in F2 generation of six virginia $X$ spanish crosses of groundnut (Arachis hypogaea L.). Legume Research. 31 (3): 210-213.

John, K., Vasanthi, R.P., Sireesha, K and Giridhara Krishna, T. 2013. Genetic variability studies in different advanced breeding genotypes of Spanish bunch groundnut (Arachis hypogaea). International Journal of Applied Biology and Pharmaceutical Technology. 4 (2): 185-187.

Johnson, H.W., Robinson, H.F and Comstock, R.E. 1955a. Estimates of genetic and environmental variability in soybean. Agronomy Journal. 47: 413-418.

Jonah, P. M., Aliyu, B., Kadams, A.M and Jibung, G.G. 2012. Variation in pod yield characters and heritability estimates in some accessions of bambara groundnut (Vigna subterranea L.). Global Research Journal of Agricultural and Biological Sciences. 3 (4): 360-369.

Kadam, P.S., Desai, D.T., Jagdish, U., Chauhan, D.A and Shelke, B.L. 2007. Variability, heritability and genetic advance in groundnut. Journal Maharashtra agricultural University. 32 (1): 071-073.

Kamdi, S.R., Patil, S.R., Kadu, P.R., Bhasme, S.P and Kothikar, R.B. 2017. Genetic variability, correlation and path analysis in groundnut. BIOINFOLET. 14 (1): 3639.

Korat, V.P., Pithia, M.S., Savaliya, J.J., Pansuriya, A.G and Sodavadiya, P.R. 2009. Studies on genetic variability in different genotypes of groundnut (Arachis hupogaea L.). Legume Research. 32 (3): 224-226.

Lush, J.L. 1940. Inter size correlation and regression of offspring on dams as a method of estimating heritability of characters. Proceedings of American Society, Animal product. 33: 293-301.

Meta, H.R and Monpara, B.A. 2010. Genetic variation and trait relationships in summer groundnut (Arachis hypogaea L.). Journal of Oilseeds Research. 26: 186-187.

Narasimhulu, R., Kenchanagoudar, P.V and Gowda, M.V.C. 2012. Study of genetic variability and correlations in selected groundnut genotypes. International Journal of Applied Biology and Pharmaceutical Technology. 3 (1): 355358.

Parameshwarappa, K.G., Kruparani, K.S and Bentur, G.M. 2005. Genetic variability 
and character association in large seeded groundnut genotypes. Karnataka Journal Agricultural Sciences. 18 (2): (329- 333).

Patidar, S., Rai, P.K and Kumar, A. 2014. Evaluation of groundnut (Arachis hypogaea L.) genotypes for quantitative character and yield contributing traits. International Journal of Emerging Technology and Advanced Engineering. 4 (7): 500- 504.

Patil, A.S., Punewar, A.A., Nandanwar, H.R and Shah, K.P. 2014. Estimation of variability parameters for yield and its component traits in groundnut (Arachis hypogaea L.). The Bioscan. 9 (2): 749754.

Satish, Y. 2014. Genetic variability and character association studies in groundnut (Arachis hypogaea L.). International Journal of Plant, Animal and Environmental Sciences. 4 (4): 298 300.
Shukla, A.S and Rai, P.K. 2014. Evaluation of groundnut genotypes for yield and quality traits. Annals of Plant and Soil Research. 16 (1): 41-44.

Sudhir, K.I., Venkataravana, P and Gururaja Rao, M.R. 2008. Evaluation of new germplasm and advanced breeding lines of groundnut (Arachis hypogaea L.) under late kharif situation. Legume Research. 31 (4): 254-258.

Vasanthi, R.P., Suneetha, N and Sudhakar, P. 2015. Genetic variability and correlation studies for morphological, yield and yield attributes in groundnut (Arachis hypogaea L.). Legume Research. 38 (1): 9-15.

Zaman, M. A., Tuhina-Khatun, M., Ullah, M. Z., Moniruzzamn, M and Alam, K. H. 2011. Genetic variability and path analysis of groundnut (Arachis hypogaea L). The Agriculturists. 9 (1\&2): 29-36.

\section{How to cite this article:}

Aparna, P., M. Shanthi Priya, D. Mohan Reddy and Latha, P. 2018. Estimation of Genetic Parameters in Groundnut (Arachis hypogaea L.) for Yield and It's Contributing Characters under Inorganic Fertilizer Managements. Int.J.Curr.Microbiol.App.Sci. 7(04): 1559-1565. doi: https://doi.org/10.20546/ijcmas.2018.704.175 